\title{
EXECUÇÃO PROVISÓRIA NO PROCESSO CIVIL ${ }^{4}$
}

\author{
MAURÍCIO MANICA GÖSSLING
}

Data da defesa: $13 / 12 / 2004$

\section{RESUMO}

A presente dissertação tem como objeto de estudo a execução provisória, com abordagem especialmente voltada para o direito processual civil brasileiro. A pesquisa está estruturada em quatro capítulos. O primeiro deles trata de aspectos teóricos da execução provisótia, aí incluídas questões conceituais e terminológicas, a relação do tema com os efeitos recursais, a natureza jurídica do instituto e as espécies sentenciais exequíveis. Ainda no capírulo exordial, defende-se uma visão unitária do instituto, capaz abrigar sob o mesmo título a tutela antecipada. O segundo capírulo é de dicado à história da execução provisória e sua situação no direito estrangeiro. No terceiro, discute-se a dimensão axiológica da execução provisória. São analisados os valores prestigiados pelo instituto e, em seguida, os riscos que the são inetentes, no intento de buscar um ponto de equilíbrio entre efetividade e segurança jurídica. Por derradeiro, ganham atenção questões dogmáticas, ultimamente enfrentadas pelos operadores do direito.

4 Sob a orientação do Professor Doutor Carlos Alberto Alvaro de Oliveira, Professor Titulat da Universidade Federal do Rio Grande do Sul, Doutor em Dixeito pela Universidade de São Paulo, contando com a participação do Professor Doutor Darci Guimarães Ribeiro, da Universidade do Vaje do Rjo dos Sinos, Doutor em Direito pela Universidad de Barcelona, U.B., Espanha; pelo Professor Doutor Paulo Henrique dos Santos Lucon, Professor da Universidade de São Paulo, Doutor em Direito pela Universidade de São Paulo e pelo Ptofessor Doutor José Maria Rosa Tesheiner, Professor adjunto da Universidade Federal do Rio Grande do Sul, e Livre Docente pela Universidade Federal do Rio Grande do Sul. A referida deresa foi presidida pelo Professor Doutor Carlos Alberto Alvaro de Oineira. 